Book Reivew

\title{
Muslim Communities in North America
}

\author{
Edited by Yvonne Haddad and Jane Smith. Albany: State \\ University of New York Press, 1994, 545 pp.
}

This book, which is a collection of 22 articles by 25 authors, is appropriate for undergraduate courses on religion in the United States, religious minorities, immigrant communities, the history of religion, and the sociology of Islam and Muslims. The first part contains five articles on religious communities, the second part has nine articles on the mosaic of Islamic communities in major American metropolitan centers, and the third part consists of eight articles on ethnic communities in metropolitan settings. Each part should have been a separate book, as this would have made the book less bulky and more accessible to those who are interested in only one of the areas covered.

Reading this book makes it clear that there is great need for Muslim scholars to study and analyze their own communities, which have a rich history and have only been studied recently. Books such as this are an important contribution to the understanding of Muslims in the West and also serve to clear up many misconceptions about Muslims, a development that makes interfaith and intercommunity dialogue easier.

Part 1 begins with an article on the Shi'ah communities in North America by Abdulaziz Sachedina (professor of religious studies, Univer- 
sity of Virginia). He claims that at least 30 percent of the total Muslim population of North America is Shi'ah and also notes that many African Americans have become dissatisfied with the Sunni Arab interpretation of Islam, which tends to legitimize and support Arab Muslim governments. In addition, many African Americans are attracted to the activist leadership style that the followers of Ayatollah Khomeini possess. This has caused some African American Sunnis to become Shi'is, a phenomenon that shows no sign of abating. This article provides a good picture of the Shi'ah communities in North America in general and sets the framework for further studies of particular Shi'ah communities in major cities.

Mukhtar Curtis (imam at the Federal Correctional Institution in Milan, Michigan) writes about the Dar-ul-Islam movement. Jamil AlAmin, a resident of Atlanta, Georgia, is the national amir. The Dar, founded by Rajab Mahmud, Ishaq Abdushshaheed, and Yahya Abdulkareem in 1962, was one of the first African American Sunni Muslim groups to be established in the United States. Its first mosque was founded in Brooklyn in 1962. Dar-ul-lslam was the largest indigenous Sunni Muslim group in the United States until 1975, when Warith Deen Muhammad proclaimed Sunni Islam to be the religion of the Nation of Islam, which then had a membership of one hundred thousand.

Mukhtar Curtis provides excerpts from Al-Jihadul Akbar, the journal of the movement. He points out two major upheavals in the history of the Dar. In 1968, FBI agents came to the Brooklyn mosque and, while claiming to be looking for a fugitive, trashed it. In 1980, the Dar split into two groups, after its leader, Imam Yahya, declared that the Dar had ceased and was from that moment on under the leadership of the Sufi Shaykh Mubarak Ali Jilani. Those who continued to follow Imam Yahya now consider themselves Sufis. Those who refused to do so formed another Dar that is half the size of the former Dar and are known as the National Jama'ah. Their leader is Jamil Al-Amin.

Since little has been written about the Dar, Mukhtar Curtis provides a much-needed history of this important Muslim group. His historical presentation provides yet another example where friction has occurred between indigenous and immigrant Muslims. He points out that the Dar was based on a commitment to Islam and an African American nationalist consciousness that sought to establish a sense of control for African Americans.

Why has the Dar not become the largest African American Muslim organization today? This question remains to be answered, especially since its ideology (more than any other African American Muslim group) has been closer to the ideology of immigrant Muslims.

Yusuf Nuruddin (Medgar Evers College, New York) writes about the Five Percenters, a splinter group that, under the leadership of Clarence $13 X$, broke away from the Nation of Islam in 1964. They believe that they are the chosen 5 percent of humanity and are the only true Muslims. This group was primarily responsible for disseminating, popularizing, and reinterpreting the teachings of Elijah Muhammad among the teenage gen- 
eration of the 1960s in the New York metropolitan area. The Five Percenters are now known as The Nation of Gods and Earths.

Many of the lyrics in contemporary rap music make direct reference to Five Percenter ideology. Some of the reasons for the popularity of Five Percenters include: their use of eloquent slang speeches to spread their message, outreach efforts in poor African American neighborhoods, and a focus on teenagers. They are considered non-Muslim by orthodox Muslims because of their teachings, which include the following: the African American man is God and his proper name is Allah (Arm Leg Leg Arm Head), and the Science of Supreme Mathematics is the key to understanding the individual's relationship to the universe.

Yusuf Nuruddin points out that the Five Percenter movement is basically a youth movement, for its structure is designed especially to appeal to the youth. As Five Percenters become older and more mature, they tend to become Sunni Muslims. Will the Five Percenters continue to thrive, given the spread of orthodox Islam throughout North America? If Yusuf Nuruddin is correct in linking African American social, economic, and political conditions to the rise of the Five Percenters, then perhaps they will continue to thrive in the ghettos of American cities.

The second part looks at Muslims in Los Angeles, San Diego, Seattle, New York City, Chicago, Indianapolis, Rochester, Quincy, and Montreal. It is not clear why Washington, DC, Ottawa, and Toronto were excluded.

The article on Chicago was written by Asad Husain (professor of political science, Northeastern Illinois University) and Harold Vogelaar (scholar in residence, Lutheran School of Theology). It concentrates on immigrant Muslims, who first came to Chicago in 1885. The largest Islamic center in Chicago, the Muslim Community Center, was established in 1969. The Sufi orders, which are popular and growing in the Chicago area, are discussed in three sentences. The American Islamic College is mentioned, but there is no information given about the problems that have plagued it or its continued financial instability. Mention is made of the fact that Muslims in Chicago are buried in some local cemeteries, but the names of these cemeteries and their locations are not provided. Unlike the other articles, this one provides information about the growing number of Muslim youth groups in Chicago, which cater to teenagers, such as the local chapter of the Muslim Youth of North America.

The article on Indianapolis is by Steve Johnson (former editor of Islamic Horizons). He provides a comprehensive overview of the many Islamic groups in the city, in addition to mentioning the tensions between indigenous and immigrant Muslims. He commits a factual error by stating that "the national Muslim Student Association [begun] in Peoria, Illinois, in 1963" (p. 270). The Muslim Students Association of the United States and Canada was begun in Urbana-Champaign, at the University of Illinois. He also makes the following unsubstantiated allegations:

Some persons opposed to activist Islam have charged that IIIT [International Institute of Islamic Thought] promoted the forma- 
tion of ISNA [Islamic Society of North America] as an umbrella organization, so that IIT could have more effective control over Islamic work in the United States and Canada. Some former ISNA employees allege that ISNA's perpetual financial problems may be designed by IIIT so that it can dismiss unwanted workers under cover of financial problems. In this way, IIIT could maintain control over the grassroots Islamic activity, but not be encumbered with the daily problems of administering those activities. (p. 271)

It is unclear why he does not back up these accusations or provide the reader with the alternative viewpoint. Such statements are irresponsible in scholarly articles.

The article by Mary Lahaj (consultant and lecturer) on Quincy, Massachusetts, provides an insider's perspective on the growth of American Islamic institutions. Her grandparents were founding members of the Islamic Center of New England, which was founded in the early 1900s, by seven Lebanese immigrant families.

The history of the mosque mimics many of the struggles that other mosques in the West have gone through: between Sunnis and Shi'ahs, Arabs and South Asians, and older immigrants and more recent immigrants. The Islamic Center survived these hardships, including a fire in 1990 that destroyed its interior and caused half a million dollars worth of damage. Such articles by insiders like Lahaj are very useful for chronicling the history of Muslim institutions and for preserving the failures and successes of previous generations for the benefit of future generations.

The third part contains separate articles on the Lebanese, Albanians, and Turks in Detroit, Michigan; Yemenis in Delano, California; Iranians in Los Angeles, Califiornia; and African Americans in Poughkeepsie, New York. In addition, there is an article on elderly South Asians in an unnamed metropolitan area and one on female Yemenis and Lebanese in Dearborn, Michigan.

Fariyal Ross-Sheriff (professor of social work, Howard University) discusses the needs and challenges of elderly Isma'ili immigrants. She conducted an ethnographic study of forty men and women, aged between 55 and 85, who had immigrated from India, Pakistan, Bangladesh, Burma, Kenya, Tanzania, or Uganda. All of them had come to the United States to join their children after they had reached the age of 50. Like most elderly people, their primary desire was to feel needed by their families and their primary fear was complete dependence.

They face many new challenges, such as each generation's different worldview. The older generation values family obligations over personal achievement, whereas the younger generation values personal achievement over family obligations. The older generation prefers family activities and household chores over entertainment with friends and watching television. Furthermore, these elderly Muslims felt they were not making valuable contributions to the family or society. Thus they experienced loneliness, isolation, confusion, frustration, boredom, and depression. 
Ross-Sheriff makes the point that the Isma'ilis have established support programs to serve the elderly members of their community. These include transportation to the mosque, ethnic entertainment, and emergency crisis intervention. However, these programs are run by people who are not professionally trained social workers, who are not knowledgeable about the welfare entitlements provided by the government, and who do not have the skills needed to deal with mental health problems.

Barbara Aswad (professor of anthropology, Wayne State University) discusses the attitudes of Yemeni and Lebanese women in the Dearborn, Michigan, area toward employment and welfare. Of the forty married women interviewed, 50 percent of the Yemeni women expressed a desire to work and 50 percent said that their husbands would not be opposed (the other half said that their husbands would be opposed). Only one of the Yemeni women had ever been to school. Most of the Lebanese women expressed a desire to work and said that their husbands would not mind if they did so. Sixty percent of the Lebanese women had never been to school. Aswad also found that many women find it difficult to accept welfare, for it can be a source of shame and lead to dependence.

This article is important, for it is part of a new generation of articles that consist of direct interviews with Arab Muslim women in order to learn about their situation. Their opinions, as opposed to somebody else's opinion of women, are recorded. Although it mentions the role of religion in shaping women's attitudes and behavior, it does not clarify how they interpret Islam in their attempt to facilitate their survival in a non-Muslim society. Are these women seeking more religious education to help them cope with their lives? If yes, who is providing it?

This book raises many important issues: the role of women in American Muslim communities; efforts to survive in a non-Muslim environment and to reach out to non-Muslim communities; minority-majority relations and the differential access of North American Muslim communities to power, wealth, and prestige; the maintenance of a Muslim identity; assimilation vs. preservation; and the urbanicity of Muslims in the West. After reading the book, one obtains a good sense of the varied history of American Muslim communities. Every American Muslim should know this history in order to understand his/her own community. All of the Muslim communities mentioned in the book are still functioning. An interesting companion book would be a study of Muslim communities that did not survive.

The publisher should have provided a glossary of Islamic and foreign terms. Furthermore, there should have been a list of American Muslim organizations and mosques in order to help the reader make sense of the wide variety of Muslim institutions in the United States and Canada.

Omar Altalib Department of Sociology University of Chicago Chicago, Illinois 